\begin{tabular}{|l|l|l|}
\hline \multicolumn{2}{|c|}{ PublisherInfo } \\
\hline \hline PublisherName & $:$ & BioMed Central \\
\hline \hline PublisherLocation & $:$ & London \\
\hline \hline PublisherImprintName & $:$ & BioMed Central \\
\hline \hline
\end{tabular}

\title{
Role of PGE2 receptors in RA
}

\begin{tabular}{|c|c|c|}
\hline \multicolumn{3}{|c|}{ ArticleInfo } \\
\hline ArticleID & : & 250 \\
\hline ArticleDOI & : & 10.1186/ar-2002-78201 \\
\hline ArticleCitationID & : & 78201 \\
\hline ArticleSequenceNumber & : & 3 \\
\hline ArticleCategory & : & Paper Report \\
\hline ArticleFirstPage & : & 1 \\
\hline ArticleLastPage & : & 3 \\
\hline ArticleHistory & : & $\begin{array}{ll}\text { RegistrationDate } & : 2002-10-1 \\
\text { Received } & : 2002-10-1 \\
\text { OnlineDate } & : 2002-11-20\end{array}$ \\
\hline ArticleCopyright & : & Biomed Central Ltd2002 \\
\hline ArticleGrants & 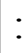 & \\
\hline ArticleContext & : & 130754411 \\
\hline
\end{tabular}


Elaine Lidington, ${ }^{\text {Affl }}$

Aff1 Imperial College London, UK

\section{Keywords}

Collagen antibody induced arthritis, EP4 receptor, PGE2

\section{Context}

Nonsteroidal anti-inflammatory drugs (NSAIDs) inhibit cyclooxygenase (COX) activity and the production of downstream prostanoids, such as prostaglandin E2 (PGE2). NSAIDs are widely used in treatment of a range of arthropathies. A previous study in a rat model showed that neutralisation of PGE2 with antibodies significantly reduced antigen-induced arthritis. However, it is not certain which of the four known PGE2 receptors (EP1-4) are involved in the pathogenesis of arthritis. With this question in mind the authors measured the incidence and severity of arthritis in mice deficient in each of the four EP receptors, using a model of collagen antibody induced arthritis (CAIA). This work sought to understand how prostaglandins function in joint inflammation.

\section{Significant findings}

Homozygous deletion of EP1, EP2 or EP3 did not affect the development of collagen antibody induced inflammation. However, EP4 receptor deficient mice showed reduced incidence and severity of arthritis at all time points up to 11 days, as determined by paw examination, and histologically demonstrated reduced Mankin (less hyperplasia, proteoglycan loss, pannus formation and cartilage destruction) and type II collagen breakdown scores. Looking at clinical biomarkers they found reduced SAA levels, serum IL-6, peritoneal IL-6 and PGE2 in EP4 deficient animals (although they still produced IL-6 in response to LPSinjection). Liver and peritoneal macrophages from diseased wild type mice expressed EP4 receptor mRNA. The level of IL-1 $\beta$ mRNA was lower in the liver of arthritic EP4 deficient mice, and IL-6 secreted from peritoneal macrophages isolated from arthritic EP4 deficient mice was also reduced. This, the authors conclude, showed that both systemic and hepatic inflammatory processes had been inhibited by genetic depletion of the EP4 receptor.

\section{Comments}


This study points to a major role for PGE2 in arthritis in mice, with the COX-2-dependent PGE2 response being mediated by EP4 receptors in both the systemic and local inflammatory responses associated with arthritis. It was noted that genetic depletion of COX-2 results in a similar resistance to arthritis as that observed in this study. However, the commentary that accompanies this article observes that only certain patients benefit from NSAIDs, often to a limited extent, and further work will clearly be required to see if EP4 antagonists are more effective than COX-2 inhibitors in the clinic. It is possible that inhibition of prostaglandin synthesis is simply incomplete using COX-2 antagonists or that other unidentified ligands act on EP receptors. Moreover, homeostatic biologic activities of EP4 receptors may also be relevant in this context.

\section{Methods}

EP4 receptor deficient mice, collagen antibody-induced arthritis, paw examination, 9A4 staining, Manakin scale for safranin O staining, ELISA for serum, PGE2, IL-6, SAA, RT-PCR for EP4, Quantakine mRNA kit for IL-1 $\beta$

\section{References}

1. McCoy JM, Wicks JR, Audoly LP: The role of prostaglandin E2 receptors in the pathogenesis of rheumatoid arthritis. J Clin Invest. 2002, 110: 651-658. 